\title{
STUDENT'S ATTITUDES TOWARDS CHILDREN WITH DISABILITY
}

\author{
Author: \\ Anita Krausz \\ Szegedi Tudományegyetem JGYPK \\ E-mail address: \\ krauszanita@jgypk.szte.hu
}

\author{
Lectors: \\ Tímea Meggyesné Hosszu (Ph.D.) \\ Szegedi Tudományegyetem JGYPK \\ Imre Varga (Ph.D.) \\ Szegedi Tudományegyetem JGYPK \\ ... and two other anonymous reviewers
}

Krausz, A. (2020). Student's Attitudes Towards Children with Disability. Különleges Bánásmód, 6. (3). 7-15. DOI $10.18458 /$ KB.2020.3.7

\begin{abstract}
Several studies have shown that the integrated education has advantages in students' social development and accepted attitude development (Meyer, Park, Grenot-Scheyer, Schwartz \& Harry, 1998). The studies about the integrated education had been traced for several decades, our research is based on the CATCH (Chedoke-McMaster Attitudes Towards Children with Handicaps Scale) questionnaire (Rosenbaum, 1985) which instrument had been used in several international studies as well (Tirosh, 1997; Vignes, 2008; Godeau 2010; Bosseart, 2011; De Laat, 2013, Schwab, 2017). Our major aim is to map the adolescent youth, their attitudes towards children with special treatment. The questionnaire was based on the threecomponent model of attitudes proposed by Triandis (1971). This 36-item, self-administered scale was primarily paper based, but our adaptation is placed to online form. The participants of the study were 7th grade students $(N=99)$ The overall reliability of the test was satisfactory (Cronbach- $\alpha=0,856)$. In the content analysis we found two items which were significantly negative and four items which were not significant, those leaving the $\mathrm{KMO}=0,809(\mathrm{KMO}>6)$, therefore suitable for factor analysis. The results show that, however in our sample these three-component factor aren't so clear, the test is reliable. There are some subtests which call for revision, and we will need further researches to develop our assessment tool to make it more reliable and valid.
\end{abstract}

Keywords: CATCH (Chedoke-McMaster Attitudes Towards Children with Handicaps Scale) questionnaire; special educational needs, inclusion; disabled; handicapped

Disciplines: pedagogy

\begin{abstract}
Absztrakt
FOGYATÉKOSSÁGGAL KAPCSOLATOS TANULÓI ATTTITŰD

Az együttneveléssel foglalkozó kutatások a tanulók szociális területen megmutatkozó fejlődését hangsúlyozzák (Meyer, Park, Grenot-Scheyer, Schwartz és Harry, 1998). Az integrált oktatással kapcsola-
\end{abstract}


tos tanulmányok évtizedek óta foglalkoznak a tanulói attitűddel, kutatásunk a CATCH (ChedokeMcMaster Attitudes Towards Children with Handicaps Scale) kérdőíven (Rosenbaum, 1985) alapul, mely az utóbbi évek több nemzetközi mérésének is eszközéül szolgált (Tirosh 1997; Vignes, 2008; Godeau 2010; Bosseart, 2011; De Laat, 2013, Schwab, 2017). Célunk a serdülőkorú fiatalok, fogyatékos gyermekek iránti attitűdjének feltérképezése. A kérdőív a Triandis (1971) által javasolt háromkomponensű attitúd modellre épült. A 36 itemből álló skála eredetileg papír alapú volt, amit mi online formában alkalmaztunk a mintánkon. A vizsgálat résztvevői 7. évfolyamon tanuló diákok voltak $(\mathrm{N}=99)$. A teszt általános megbízhatósága kielégítő volt (Cronbach- $\alpha=0,856)$. A tartalomelemzés során két olyan elemet találtunk, amelyek szignifikánsan negatívak voltak, és négy olyan elemet, amelyek nem voltak szignifikánsak, azokat elhagyva a $\mathrm{KMO}=0,809(\mathrm{KMO}>6)$, mely alapján alkalmasnak találtuk a faktoranalízishez. Az eredmények alapján elmondható, hogy az eredeti háromkomponensủ tényező nem mutatkozik meg világosan a mintán, de ennek ellenére a teszt megbízhatónak bizonyult. A jövőben néhány szubteszt, felülvizsgálatot igényel, illetve további kutatásokra is szükség van az értékelési eszköz fejlesztéséhez, hogy megbízhatóbbá és érvényesebbé váljon.

Kulcsszavak: CATCH (Chedoke-McMaster Attitudes Towards Children with Handicaps Scale) attitűdmérő kérdőív; sajátos nevelési igény; inklúzió, fogyatékosság

Diszciplina: pedagógia

It is still contested whether the individual's attitude with an object, a person or a group is related to his or her behavior with the same object, person or group. According to Cohen (1960) and Gerard (1966) the individual tends to adapt his attitudes to his behavior. In the last few years, researchers have studied attitudes in multidimensional aspect. Rosenbaum (1985) with the CATCH questionnaire also used the multidimensional point of view, that's why we adopted it and used among Hungarian students. Our main goal was to map out the adolescent youth, in specifically their attitudes towards children who require special treatment due to some developmental difficulties. Several previous studies have shown that the integrated education has a good effected on most of the student's social development. What is more, it also is proven to have positive influences on attitude development (Meyer, Park, Grenot-Scheyer, Schwartz \& Harry, 1998).
For the more complex personal development of the students is definitely better that they meet and learn more about the otherness as soon as possible (Irvine, 2012). On the contrary, as it has been highlighted by formerly done research, inclusion in itself does not mean an automatic improvement of the social connections and friendship between those children who have special needs and those who do not (Bosseart, 2011). However, we can find all sorts of differences in integrated education which may suggest that it is not homogeneous. In practice, one can encounter several subtypes such as local, functional and social integration. We speak about local integration if all children are educated in the same building, however, there is no connection between those who have special needs and the typically developing ones. At the case of social integration, separation is applied to lessons, on the other hand students are together during time spent 
in schools outside of the actual classroom activities. The third and final form is functional integration, also known as "full integration". At the case of full integration each and every child is involved in the activities of the school, without making any differentiation between them. Students learn together with their peers, their mental and social development is being fostered not only by pedagogical methods and the teacher him or herself but also by cooperation with each other. In this case, when integrated children learn in the same classroom, teachers also need to be prepared to face the challenges. For example they need to have useful knowledge about supporting pedagogical methods and models of teaching forms. These include being aware and ready to improve themselves and their already existing skills. It is worth it to mention that there are reversed integration. It means that a typically developing student is welcomed in an institute that is especially for special educational needs kids. Considering its possible forms, one can find rigid or spontaneous integration, at the case of which a yet undiagnosed child is left in a mainstream school. The reason why integration is really needed is because time spent together promotes the development of acceptance attitudes.

Our results in terms of the domestic conditions are especially important and it may contribute to the proper functioning of integration). The studies about the integrated education are traced for several decades, we used the CATCH (ChedokeMcMaster Attitudes Towards Children with Handicaps Scale) questionnaire (Rosenbaum, 1985) which instrument are used in a number of international research (Tirosh, 1997; Vignes, 2008; Godeau 2010; Bosseart, 2011; Abiola, 2012; De Laat, 2013, Schwab, 2017). In the last years so many countries used this scale, this resulted in changing education policies and in making regular education the standard provision for all students, including those with special educational needs. As far back as in the 1980s Rosenbaum thought it im- portant to reveal the students attitudes towards disability. The CATCH questionnaire has been shown to contribute to the integrated and inclusive education and the training organization processes, programs. Primarily, the questionnaire was designed for primary school children, especially for the 7 th grade students, accordingly, the language of the questions was adjusted to the student's age. The test deals with attitudes towards students with special needs. The attitude is the major component of the social behavior, ,a mental and neural state of readiness, organized through experience, exerting a directive or dynamic influence upon an individual's response to all objects and situations with which it is related" (Allport, 1935).

The integrated education is one of the most problematic question in the education all over the world. For successful social integration we have to start on a small scale, with educational integration. And of course, if we talk about integrations, we do not only focus on disabilities but also we need to take people of different racial, ethnic and religious background into consideration. However, this present pilot research only chooses to pay attention to and investigate individuals' attitude toward special educational needs. Nevertheless, in some cases it goes in hand since one appears together with the other. Special education in Hungary are designed for those students who are mentally, physically, socially and/or emotionally delayed. This aspect of this delay, categorized as a developmental delay, signifies an aspect of the child is overall development (physical, cognitive, scholastic skills) which place them behind their peers. The integration has a long history from Nirje's normalization pursuit in the 1960s, but it wasn't solvable in every country. In terms of forms and the type of the problems there are differences in every country. The road towards inclusion is also very different in each society. There are difficulties in making inclusive education happen triggered researchers to think about the reasons for this. Authors point at the key role 
that teachers play in realizing inclusive education (Meijer 2003; Norwich 1994). The most important thing is the attitudes, but those of others directly involved, like parents and students, are of relevance as well. According to Stoiber et al. (1998), the voices of those directly involved in change should be heard because they provide valuable "inside" perceptions and information (de Boer et al, 2012).

This study is about a Hungarian adaptation of CATCH attitude scale (Rosenbaum, Armstrong, \& King, 1986), we used it in the 2016-2017 school year. In Hungary there was more than 88,000 SEN students in that year, from the 1,5 million students who's been in the school system. Now we have almost similar number for SEN students. From the European Agency (2017) datas the most of the Hungarian SEN students learn inclusive $(60 \%)$ and the segregated $(35 \%)$, but rather we call it integrated not inclusive. In the education the integrated efforts begins in the 1980s but it is still in process, it depends on the governments and laws.

\section{Theoretical background}

In order to find out more about the impact of integrated education, we need to look at the student's attitudes toward peers and the components of these attitudes. Understanding our behavior and predicting our actions means the common point of attachment of many disciplines. Our attitudes help us to find out what are good, beautiful, useful and what are false, ugly and useless for us and for our environment (Csepeli, 2014).

When defining attitudes, the agreement of researchers is that the attitude is a mental (cognitive) representation which sums up our prejudice with objects, thereby guiding our behavior and organizing our knowledge from the world. The structure of the attitude thoughts on the subject of it and the mental (cognitive, affective) components of attitudes.
The attitude can be a subject of a person, a group of physical objects, but it can be an abstract idea as well. It determines to our behavior, often rooted in belief, resulting in emotion (positive or negative) in relation to the subject, resulting in intentional behavior towards the subject (Meyers, 2014). Undoubtedly, it is connected with our behavior or our possible behavior, and there is certainly formatted and therefore can be shaped. This linkage makes the attitude of the most important point, which effectively scales all the objects, phenomena and moments of our world (Meyers, 2014).

The attitude definition is usually based on the wording of Allport (1954) definition. Rosenberg and Hovland (1960), one of the major breakthroughs in the research of attitudes, represented a triple structure in their theory. Attitudes usually characterize these three components - cognitive, emotional (affective) and behavioral components and their hierarchical, systematic organization. The negative attitudes with the disability characterize our society, although the law provides for equal opportunities. Students' rights to be educated in mainstream schools has been legislated in Hungary since 1993, but the social tolerance, including teachers' inclusive approach towards the students with special educational need has been changing very slowly. However, in the developing countries the integration efforts have begun about 40 years ago. Nowadays there are modern supportive systems is in place, in order to look after a child's individual needs, based on the results of the diagnostic process. That means student with special needs can be educated in the following settings: an inclusive mainstream class, a special class in a mainstream school or in a special school. Children with special educational needs (SEN) are children with special rather than peculiar (as the Hungarian translation of the term would suggest) educational needs or children suffering from other types of, and sometimes more severe difficulties, who need rehabilitative support (Csépe, 2009). 


\section{Method}

\section{Participants}

The questionnaire was completed with 99 students without disabilities in the 7 th grade, which means they were 12-13-year-olds when we used it. Originally this questionnaire was designed for this age (9-13), but for us it was just a pilot study and in the future we would like to use it in other grades too. In terms of the target group the questionnaire was designed for teenagers but the researchers used the test in other age groups (9-18 age) as well. So each participants of the study were 7 th grade students $(\mathrm{N}=99)$. These 36 self-administered items in the questionnaire was primarily paper based, but our adaptation is placed to online form. Children answer statements assessing the cognitive, behavioral and affective attitude components, 12 statements for each component according to Triandis (1971) definition.

\section{Measure}

The questionnaire consists of 36 items based on the students' knowledge, feelings and experiences about certain disabilities. We adapted all of the 36 items for an online platform, called eDia (Csapó, 2009). This platform was invented with diagnostic aims which assist pedagogics in order to learn more about children's knowledge concerning Mathematics, Sciences, writing and reading comprehension and some other fields that can be used in different levels of the school systems. Using the online form is found to be easier for the students and that kind of assessment is better for the motivation. The scale is embracing three dimensions of attitudes and rates on a 5 -point Likert scale $(0$, strongly disagree to 4 , strongly agree) (Figure 1.). These three dimensions: (1) an affective component involving statements of feelings towards disabled children; (2) a behavioral intent component involving statements of what a child would do with a disabled child and (3) a cognitive component involving ver- bal statements of belief about disabled children (Triandis 1971).

CATCH contains 12 items in each component equally and it use negatively and positively worded items too, 18 of each type of them. Negatively worded items are inversely coded. These are arranged in a randomly formulated order, with an alternation of positive and negative statements.

The original CATCH questionnaire used the term „handicapped children”, we translated it for "children with special needs", but it was rather difficult to understand for the sample so it needed to be changed for „children with disabilities”.

The translation helps a lot to fill this, that „Being handicapped means having trouble walking, talking, using your arms and hands, seeing, hearing or: learning. Usually people who have handicaps have them for a 1-period of time unlike other people who may have a cold or a broken leg that usually gets better after a short time" (Rosenbaum et al,1986).

The definition of this term encountered many problems, for example legal, interpretation and vocational. As Rosenbaum used to do, we asked it from the professionals, for the English version schoolteachers and principals reviewed the study and reading levels of the statements to ensure appropriateness for the target population. Statements were reworded or dropped after feedback from the educators. Therefore, the grammar of the items is as understandable as the first version, from the translation 4 experts helped us to translate and another 4 experts helped to turn it back to the original language.

\section{Aims and Objectives of the Paper}

The main aims and objectives are the measuring attitudes of a typically developing kid toward their peers with disabilities. In addition, we also analyzed the influence of the students' gender when it came to their attitudes toward their peers with disabilities. And of course, we were curious the children knowledge about the SEN in general. 
Figure 1. The three-component concept (source: A. de. Boer et al., 2011.)

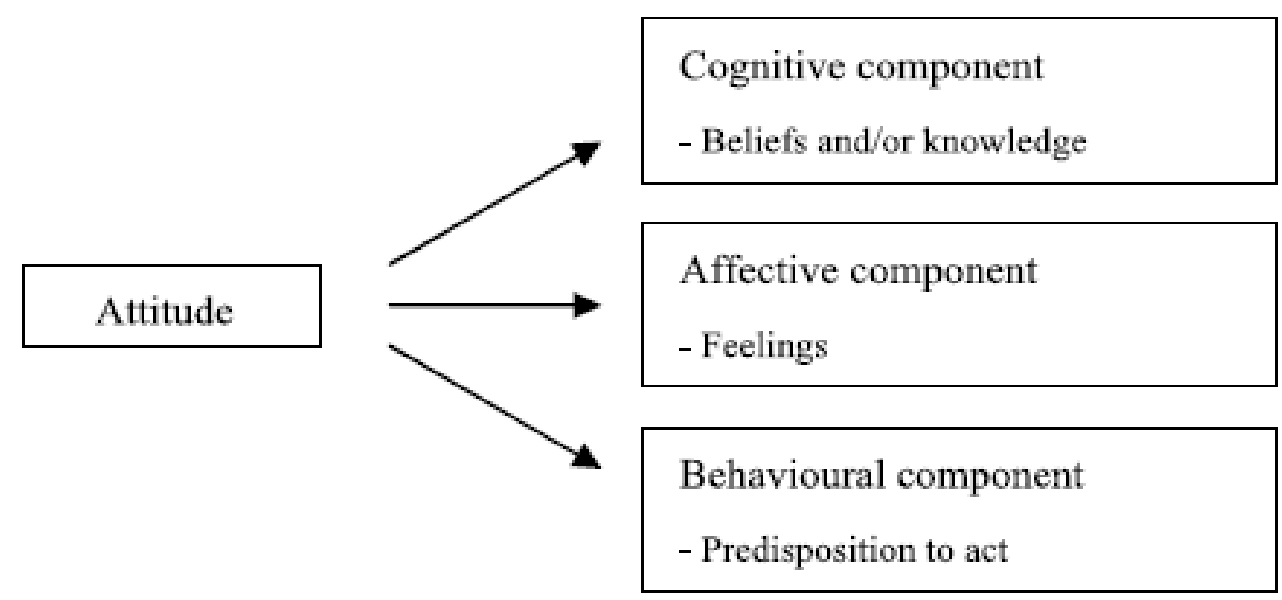

\section{Analysis}

The CATCH questionnaire was filled in by 99 children attending 7th graders in three different public elementary schools. All of the schools are integrated, but we don't have any information about the level of integration work in each schools. The kids learn in five different classes, but the classes do not differ substantively. Based on the genders there are 44 boys and 55 girls in our sample. About the analysis, the maximum ideal would be equal to 40 and the minimum would be equal to zero, after coding is made according to the rules. The results were used in calculating the following formula: number of total points per item divided by items times 10 .

\section{Results}

The overall reliability of the test was satisfactory (Cronbach $\alpha=0,856)$. In the item analysis we found four items which were significantly negative and four items which were not significant, those leaving the $\mathrm{KMO}=0,809(\mathrm{KMO}>6)$ therefore suitable for factor analysis. Factor and total scores are calculated by adding the items, dividing the sums by the number of items and multiplying it by 10 . The CATCH score of 0 point and a maximum of 40 points, with high scores indicating more positive attitudes. In this study the students' mean score was 23,77 points out of the total score, the results were supported by previous studies. The reason being, the great deviation of the samples both regarding the quality and quantity.

We found some differences in the connections between the factors and the components of the attitudes. The differentiating indicator shows to what extent does the certain item differentiate. 57\% of kids gave answer for every question which suggest us that the grammar was probably not very clear for the sample. Another possible reason for this data because of statements are not typify the disabilities. In our view it is an important part of the problem, because the individual's attitude is more positive with a person with physically disabled as a person with mental disability.

\section{Discussion}

Our results show that although in our sample these factors of Triandis (1971) are not so clear, the 
test is reliable. Beside the factor analysis we have two separate groups from the negative and the positive statements and a third factor have just one item (I would like to have a child with special needs living next door.). Based on this result we examined the statements in terms of proximity. That item was in the farthest stage. However, the other two factors proximity entirely was not separated. The opinions of the researchers were not the same about the factors, the three-component model has not been empirically replicated for either of these scales (Bossaert, 2013). More research needs to be done about the causes of the differences between the models. So the mean score was 23,77 points out of the total score, the results were supported by previous studies. As far as the international mean score is concerned, it is somewhere between 24,5 and 32,4 points. The international and national results cannot be compared and contrasted.

\section{Limitations}

One of the limitations of the study is the number of the participants, in the future we should use the questionnaire in a bigger sample. Although this measurement was the pilot study, we get reliable data from the Hungarian sample. As well as our plan for the future to separate the forms of disabilities, because the attitude can be different towards the different type of disabilities. Therefore the questionnaire needs to be changed in this viewpoint.

\section{Conclusion}

To recapitulate briefly, this study demonstrates that the social contacts established between children make a difference in the attitudes of students in the elementary schools in Hungary towards their peers who have disabilities. Children's knowledge about disabilities will be a good opportunity to develop the attitudes. However, this difference be- tween the developmental stages was marginal and non-significant among the different genders. This present pilot study can contribute to the development of knowledge about the educational system and can help to formulate inclusive education.

Students should receive information about disability, need to know more about how to tolerate the others (Osmanaga, 2013). There are some subtests which call for revision, and we will need further research to develop our assessment tools in order to make it more reliable and valid. We hope that in the future it can be useful for the developing integration and for inclusive education. In the future we are planning on using the CATCH questionnaire with a longer background questionnaire. This would aim to collect more in-depth information about contain questions concerning the children's social background, also questions would be asked in order to get to know if these children know anyone in their neighborhood, school and of course in their family with disabilities. That is, if he or she has any acquaintances who have some disabilities. It is an essential way to know more about the kids' attitude toward disabled peers. According to Bosseart (2013), having a chance to make friend and connections with typically developing students, feeling accepted by them are all crucial factors (among others) of integration. This fact proves the significance of such topic. However, there has certainly not been done an adequate amount of research resulting in the lack of knowledge that is available for us at the moment. For successful improvement the development of a good measurement system is more than necessary. Attitude measurement has proven to be indeed complicated. Based on the international literature it is a highly investigated topic. Therefore, our society needed a longitudinal research which assesses both the stability of attitudes and the direction of effects of associated variables. It is highly recommended to unravel the relations among attitudes and their associated variables. Another reason why we need a lon- 
gitudinal research because as years pass by attitudes may and most probably will alter. We need to have a longitudinal research in a big sample in order to keep a record of the attitude of the members of the sample and also the possible changes of that.

\section{References}

Bosseart, G., Petry, A., (2013): Factorial validity of the Chedoke-McMaster Attitudes towards Children with Handicaps Scale (CATCH), Research in developmental disabilities, 34(4):1336-1345. DOI: 10.1016 / j.ridd.2013.01.007

Bossaert, G., Colpin, H., Pijl, S. J., \& Petry, K. (2011). The attitudes of Belgian adolescents towards peers with disabilities. Research in Developmental Disabilities, 32, 504-529. DOI: 10.1016/j.ridd.2010.12.033

Cohen, Arthur R. (1960): Attitude Consequences of Induced Discrepancies between Cognitions and Behavior. Public Opinion Quarterly 24 (2), 297-318. DOI: $10.1086 / 266950$

Csépe, V. (2009): Caring for children with sepecial educational needs (SEN) and their rehabilitation. In Fazekas, K., Köllő, J. and Varga, J. (eds.). Green Book. For the Renewal of Public Education in Hungary. 151-178. Budapest: ECOSTAT. ISBN 978-963-06-6690-9

De Boer, A. A., Pijl, S. J., \& Minnaert, A. E. M. G. (2011). Regular primary school teachers' attitudes towards inclusive education: A review of the literature. International Journal of Inclusive Education, 15(3), 331-353. DOI: $\underline{10.1080 / 13603110903030089}$

De Laat, S. et al. (2013): Attitudes of children and adolescents toward persons who are deaf, blind, paralyzed or intellectually disabled. Research in Developmental Disabilities, 34, 855-863. DOI: 10.1016/j.ridd.2012.11.004

Fatbardha Osmanaga (2013): The Impact of the Gender on Children's Attitudes Toward Their Disabled Peers: The Albania's Case; Sociology
Study ISSN 2159-5526 Volume 3, Number 5, 363-369. DOI: $\quad 10.1111 /$ i.14698749.1997.tb07548.x.

Frostad, P., \& Pijl, S. J. (2007). Does being friendly help in making friends? The relation between the social position and social skills of pupils with special needs in mainstream education. European Journal of Special Needs Education, 22, 1530. DOI: $10.1080 / 08856250601082224$

Gerard, H. B. (1966): The effects of severity of initiation on liking for a group: A replication. Journal of Experimental Social Psychology, 1966,2,278287.

Godeau, E., Vignes, C., Sentenac, M., Ehlinger, V., Navarro, F., Grandjean, H., et al. (2010). Improving attitudes towards children with disabilities in a school context: A cluster randomized intervention study. Developmental Medicine \& Child Neurology, 52, e236-e242. DOI: 10.1111/j.1469-8749.2010.03731.x

Irvine J.J. (2012): Complex Relationships Between Multicultural Education and Special Education, An African American Perspective, Journal of Teacher Education. 63. 4268-274. DOI: $\underline{10.1177 / 0022487112447113}$

Meijer, C. J. W. (2003). Special needs education across Europe. Middelfart: European Agency for Development in Special Needs Education

Meyer et al (1998): Inclusion and the Other Kids: Here's What Research Shows so Far About Inclusion's Effect on Nondisabled Students

Pijl, S. J., Frostad, P., \& Flem, A. (2008). The social position of pupils with special needs in regular schools. Scandinavian Journal of Educational Research, 52, 387-405. DOI: $\underline{10.1080 / 00313830802184558}$

Rosenbaum, P., Armstrong, R., \& King, S. (1986). Improving attitudes toward the disabled: A randomized controlled trial of direct contact versus Kids-on-the-Block. Journal of Developmental and Behavioral Pediatrics, 7, 302-307. DOI: $\underline{10.1097 / 00004703-198610000-00005}$ 
Rosenbaum, P., Armstrong, R., \& King, S. (1986). Children's attitudes toward disabled peers: A self-report measure. Journal of Pediatric Psychology, 11, 517-530.

Schwab, S. (2017): The impact of contact on students' attitudes towards peerswith disabilities. Research in Developmental Disabilities 62. DOI: 10.1016/j.ridd.2017.01.015

Stoiber, K.C., M. Gettinger, \& D. Goetz. 1998. Exploring factors influencing parents' and early childhood practitioners' beliefs about inclusion. Early Childhood Research Quarterly 13: 107-24.
Tirosh, E., Schanin, M., \& Reiter, S. (1997). Children's attitudes toward peers with disabilities: The Israeli perspective. Developmental Medicine \& Child Neurology, 39,811-814. DOI: 10.1111/j.1469-8749.1997.tb07548.x

Triandis, H. C. (1971). Attitudes measurement and methodology. In Attitudes and attitude change (pp. 26-59). New York: Wiley.

Vignes, C., Coley, N., Grandjean, H., Godeau, E., \& Arnaud, C. (2008). Measuring children's attitudes towards peers with disabilities: A review of instruments. Developmental Medicine \& Child Neurology, 50, 182-189. DOI: 10.1111/i.1469$\underline{8749.2008 .02032 . \mathrm{x}}$ 